\title{
Rabies in Tamarins (Callithrix jacchus) in the State of Ceará, Brazil, a Distinct Viral Variant?
}

\author{
Nélio Batista-Morais/ ${ }^{+}$, Benedito Neilson-Rolim, Humberto Hugo Matos- \\ Chaves*, João de Brito-Neto*, Lúcia Maria-da-Silva
}

\author{
Secretaria Estadual de Saúde do Ceará, Av. Almirante Barroso 600, 60060-440 Fortaleza, CE, Brasil \\ *Empresa Assistência Técnica Extensão Rural do Ceará, Ematerce, Fortaleza, CE, Brasil
}

Presently, the State of Ceará reports the largest percentage of human rabies cases originated from wild animals in Brazil, transmitted by the principal simian species, the tamarin (Callithrix jacchus), found in various locations throughout the State, but concentrated along the coast. Epidemiological studies indicated that possibly the same virus caused the deaths in humans and non-human primates. This rabies virus seem to be different from all other identified so far.

Key words: rabies - tamarins - Ceará - Brazil

Rabies is a disease characterized by acute encephalitis leading to death, caused by variants of the rabies virus of the genus Lyssavirus, and the family Rhabdoviridae (Acha \& Szyfres 1986). Transmission occurs via the bite, lick or scratch of animals that have the rabies virus present in their saliva. The principal reservoirs in urban areas are dogs and cats, while in rural areas all domesticated and wild animals may be reservoirs, including bats, foxes, raccoons, and simians, including tamarins and monkeys. Until now, viral variants have not been identified in simians. The Pan American Health Organization (PAHO) has reported an increase in the incidence of diagnosis of rabies in wild animals from $12 \%$ to $21 \%$ in the past ten years (PAHO 1991). In analyzing the American continent, the PAHO has observed that in Latin America exists a larger number of rabies-infected domesticated and farm animals, whereas in North America occurs a larger number of cases in wild animals (PAHO 1996). In Brazil, 28 cases of human rabies were reported between 1981 and 1998. Transmission by simians, raccoons, and foxes, corresponded to $2.5 \%$ of all reported human cases during this period, with even more suspected unreported cases caused by these wild animals. The State of Ceará presents the larg-

\footnotetext{
${ }^{+}$Corresponding author. Fax: +55-85-488.2089. E-mail: neliom@sesa.ce.gov.br Received 21 June 1999 Accepted 1 March 2000
}

est percentage of human rabies cases originated from wild animals in Brazil, having 37\% of the human cases origin in the past decade as recorded by the Epidemiological Surveillance Sector of the State Department of Health. In Ceará, the principal simian species is the tamarin (Callithrix jacchus) found in various locations throughout the State, but concentrated along the coast where they adapt well to the coastal vegetation.

The Brazilian national database of qualified cases (Sistema de Informação de Agravos Notificáveis), registered in 1998 one case of human rabies in the city of Acaraú and another case in Camocim/Ceará, both caused by tamarins. Furthermore, in Acaraú rabies was confirmed in another tamarin during 1998. Epidemiological studies were performed for all the cases. Samples from the nervous system of two human cases and one animal case were sent for official diagnosis to the Instituto Pasteur, in São Paulo, Brazil, the reference laboratory for rabies. The tests included immunoflourescence, animal inoculation and antigenical identification through an established monoclonal antibody panel for molecular epidemiological research of rabies virus in the Americas (Diaz et al. 1994). The official diagnosis considered that all cases were caused by the same virus, and suggested that these samples found in Ceará did not correspond to any of the previously identified variants, when considering the existing panel of monoclonal antibodies used in epidemiological studies to molecularly identify rabies virus in the Americas. In short, it was suggested that there were no similarities between the previously studied strains of rabies and that found in Ceará. 
These results lead us to believe that there may exists a rabies virus strain well-adapted to the tamarin species, indicated by the epidemiological situation of rabies in Ceará and based upon these epidemiological studies by the State of Public Health Secretary. In this State, there was a large distribution of rabies in both humans and in these animals, and the human cases of rabies were transmitted by tamarins.

As presented, rabies caused by wild animals is a large public health problem, and only can be controlled by the education of a participating population, which assimilates and practices methods of prevention. In considering the possibility of a viral variant, the currently used rabies vaccine should be tested in the laboratory to verify its efficacy against this new strain identified in tamarins. Concomitantly, experiments should be performed in an attempt to orally vaccinate tamarins in the foci areas.

\section{ACKNOWLEDGEMENTS}

To Institute Pasteur, São Paulo, for their contributions in diagnosis by monoclonal antibodies mentioned in this short communication.

\section{REFERENCES}

Acha PN, Szyfres B 1986. Zoonosis y Enfermidades Transmissibles Comuns al Hombre y a los Animales, OPAS 503, Oficina Sanitaria Panamericana, Oficina Regional de la Organizacion Mundial de la Salud, Washington, $580 \mathrm{pp}$.

Diaz AM, Papo S, Rodriguez A, Smith JS 1994. Antigenic analyses of rabies-virus isolates from Latin American and the Caribbean. Zentralbl Veterinaerme Reihe B, 41: 153-160.

Mattos CC de 1999. Saguí, humans and rabies in Ceará, Brazil. International Rabies in the Americas Meeting, San Diego, CA, abstract at http:// www.caphld.org.

PAHO 1991. Rabia. Salud Pública Veterinária 23: 1-3.

PAHO 1996. Rabia en los animales. Bol Vig Epidemiol Rabia en las Américas 18: 17. 